\title{
Pedogenic iron oxides in soils of the Acre State, Brazil
}

\author{
Alberto Vasconcellos Inda ${ }^{*}$ Jessé Rodrigo Fink ${ }^{2} \odot$ Tatiele Fruett dos Santos ${ }^{1}$ \\ ${ }^{1}$ Departamento de Solos, Faculdade de Agronomia, Universidade Federal do Rio Grande do Sul (UFRGS), 91540-000, Porto Alegre, RS, \\ Brasil. E-mail: alberto.inda@ufrgs.br. "Corresponding author. \\ ${ }^{2}$ Laboratório de Solos, Instituto Federal do Paraná (IFPR), Campus Palmas, Palmas, PR, Brasil.
}

\begin{abstract}
Iron oxides are environmental indicators and influence on physical and chemical behavior of soils. This research aimed to identify and characterize pedogenic iron oxides in soils of the Acre state, Brazil. The soils developed from sedimentary rocks of the Solimões Formation. Twenty one samples of subsurface horizons were collected from ten soil profiles. Soil samples were analyzed by $x$-ray diffractometry associated to selective chemical dissolutions. Fe contents in the clay minerals (Fes), in the pedogenic iron oxides (Fed) and in the poorly crystalline oxides (Feo) were determined. The Al ${ }^{3+}$-substitution and the mean crystal diameter of goethite and hematite were estimated. Soils presented low contents of Fes and Fed. The Fed/Fes ratio indicated soils in the intermediate stage of weathering, with dominance of goethite, hematite and maghemite. This condition of weathering was confirmed by the higher frequency of goethites and hematite with intermediate A ${ }^{3+}{ }_{-}$ substitution. Goethites have isodimensional forms and hematite have flat plaques forms.
\end{abstract}

Key words: mineralogy, $x$ ray diffraction, hematite, goethite.

Óxidos de ferro pedogênicos em solos do estado do Acre, Brasil

RESUMO: Os óxidos de ferro são indicadores ambientais e influenciam o comportamento fisico e químico dos solos. Este trabalho objetivou identificar e caracterizar os óxidos de ferro pedogênicos de solos do estado do Acre, desenvolvidos de rochas sedimentares da Formação Solimões. Vinte e uma amostras de horizontes subsuperficiais de dez perfis de solos foram analisadas por difratometria de raios $x$ associada a dissoluções químicas seletivas. Os teores de Fe total (Fes), dos óxidos de Fe pedogênicos (Fed) e de baixa cristalinidade (Feo) foram determinados; e a $\mathrm{Al}^{3+}$-substituição e o diâmetro médio cristalino da goethita e da hematita foram estimados. Em geral, os solos apresentaram baixos teores de Fes e de Fed. A relação Fed/Fes indicou solos em estágio de intemperização intermediário, com dominância dos óxidos de Fe goethita, hematita e maghemita. Essa condição de intemperismo foi reforçada pela maior frequência de goethitas e hematitas com intermediária $\mathrm{Al}^{3+}$-substituição. As goethitas possuem formas isodimencionais e as hematitas ocorrem como placas achatadas.

Palavras-chave: mineralogia, difratometria de raios $x$, hematita, goethita.

Formation and stability of Fe oxides are governed by specific pedoenvironmental conditions, which makes the oxides useful indicators for pedoenvironmental and pedogenetic processes (KÄMPF \& CURI, 2000). Usefulness of iron oxides arises from their widespread occurrence in various forms and concentrations, and their degrees of crystallinity and isomorphic substitution of Fe by other cations (INDA JUNIOR \& KÄMPF, 2005). Also, Fe oxides have physical and chemical effects on soil that depend on their specific surface area, reactivity and variability in surface charge.

Studies on $\mathrm{Fe}$ oxides have facilitated the interpretation of past and present pedogenetic processes (INDA JUNIOR \& KÄMPF, 2005), and the mapping and classification of soils (SANTOS et al., 2013). Whereas hematite, goethite and maghemite prevail in aerobic pedoenvironments, magnetite, which is a mineral of lithogenic origin, usually occurs at lower concentrations and ferrihydrite is typically present in small amounts. In cyclically anaerobic pedoenvironments, goethite, lepidocrocite and ferrihydrite are abundant, whereas hematite is restricted to mottles and nodules. Other mineralogical properties such as crystallinity and the degree of $\mathrm{Al}^{3+}$ substitution (viz., the extent to which $\mathrm{Fe}$ is replaced with $\mathrm{Al}$ ) are also effective environmental indicators and reflect specific mineral formation conditions. These mineral properties can be assessed by X-ray (XRD) diffraction spectroscopy, 
which allows mean coherence lengths (MCL) and $\mathrm{Al}^{3+}$ substitution to be estimated (SCHULZE, 1984; SCHWERTMANN et al., 1979).

In this research, we used the XRD technique in combination with selective dissolution treatments to identify and characterize pedogenic $\mathrm{Fe}$ oxides in soils from the Brazilian state of Acre. Twenty one samples were collected from the subsurface horizons of soil profiles located between the municipality of Cruzeiro do Sul and the city of Río Branco along the BR 364 road (ANJOS et al., 2013). Soils originated from Cenozoic sedimentary rocks including lacustrine argillites, siltites and sandstonites in the Solimões formation under the influence of sedimentary deposits in the foothills of the Andean mountain range. The target soils were examined at the IX Brazilian Meeting for Soil Classification and Correlation in 2010.

Fe forms were selectively extracted from the air-dried fine earth fraction (ADFE, particle diameter $<2 \mathrm{~mm}$ ). The amount of $\mathrm{Fe}$ extracted by sulfuric acid (DONAGEMA et al., 2018) was taken to represent total $\mathrm{Fe}$ (Fes). The combined amount of pedogenic oxides (Fed) was extracted with sodium dithionite-citrate-bicarbonate (DCB $\mathrm{Na}$ ) at $80^{\circ} \mathrm{C}$ (MEHRA \& JACKSON, 1960), and that of low-crystallinity oxides (Feo) with $0.2 \mathrm{~mol} \mathrm{~L}^{-1}$ ammonium oxalate at $\mathrm{pH} 3$ in the dark (MCKEAGUE \& DAY, 1966). Finally, all dissolved $\mathrm{Fe}$ forms were determined by atomic absorption spectroscopy (AAS), and total organic carbon (TOC) in ADFE was quantified by oxidation with potassium dichromate (ANJOS et al., 2013).

The Fe oxide fraction was concentrated by addition of a hot $5 \mathrm{~mol} \mathrm{~L}^{-1}$ solution of $\mathrm{NaOH}$ (KÄMPF \& SCHWERTMANN, 1982). XRD spectra were acquired with a Philips diffractometer equipped with a $\mathrm{Fe}$ monochromator, using $\mathrm{Fe}-\mathrm{K} \alpha$ radiation at $30 \mathrm{kV}$ at $30 \mathrm{~mA}$. Measurements were made on non-oriented slides of the concentrated iron oxide fraction over the ${ }^{\circ} 20$ range $25-50$. For this purpose, an amount of $300 \mathrm{mg}$ of sample was mixed with $30 \mathrm{mg}$ of halite $(\mathrm{NaCl})$ that was used as internal standard.

The hematite/(hematite+ goethite) ratio, $\mathrm{Hm} /(\mathrm{Hm}+\mathrm{Gt})$, was estimated from the area ratio of the line $\mathrm{Hm} 104$ or $\mathrm{Hm} 012$ to the line Gt 100, and the degree of $\mathrm{Al}^{3+}$ substitution in hematite was calculated from the $\mathrm{d}(110)$ spacing (SCHWERTMANN et al., 1979) in hematite, and the $\mathrm{d}(110)$ and $\mathrm{d}(111)$ spacing in goethite (SCHULZE, 1984). Finally, crystallinity was estimated from the mean coherence lengths (MCL) in the hkl planes
110 and 111 in Gt, and 104 and 110 in Hm (INDA JUNIOR \& KÄMPF, 2005).

As can be seen from Table 1, Fes values ranged from $6.3 \mathrm{~g} \mathrm{~kg}^{-1}$ in profile AC 01 (sandy sediments) to $73.4 \mathrm{~g} \mathrm{~kg}^{-1}$ in AC 06 (sandstone and clay sediments). Based on the Brazilian System of Soil Classification (SANTOS et al., 2013), the Fes values were typical of mesoferric soils $\left(80 \mathrm{~g} \mathrm{~kg}^{-1}<\mathrm{Fe}_{2} \mathrm{O}_{3}<180 \mathrm{~g} \mathrm{~kg}^{-1}\right)$ in five horizons and hypoferric soils $\left(\mathrm{Fe}_{2} \mathrm{O}_{3}<80 \mathrm{~g} \mathrm{~kg}^{-1}\right)$ in all others. Fed values ranged from 0.6 to $43.3 \mathrm{~g} \mathrm{~kg}^{-1}$ and Feo values from 0.2 to $2.7 \mathrm{~g} \mathrm{~kg}^{-1}$. The $\mathrm{Fed} / \mathrm{Fes}$ ratio spanned the range $0.10-0.67$ but most values were lower than 0.5 (Table 1), which suggests that a substantial proportion of Fe was present as primary and secondary aluminosilicates (KÄMPF \& CURI, 2000). Based on the negative correlation with index $K_{\mathrm{i}}(\mathrm{R}=-0.791, \mathrm{P}<0.001, \mathrm{n}=15)$ previously reported by ANJOS et al. (2013), the Fed/Fes ratio was a useful indicator of weathering in most of the studied soils. The Feo/Fed ratio range from 0.01 to 0.83 but was less than 0.10 in most cases, suggesting a prevalence of crystalline forms (goethite, hematite and maghemite); also, the contents in poorly crystalline oxides - ferrihydrite, mainly — were comparatively low (SCHWERTMANN et al., 1982). The prevalence of poorly crystalline oxides in profile AC01 was a result of the restrictive effect of organic matter on iron oxide crystallinity as suggested by the positive correlation between the Feo/Fed ratio and the TOC content: $\mathrm{Feo} / \mathrm{Fed}=$ $0,158+0.0656 \cdot \mathrm{TOC}, \mathrm{R}=0.861, \mathrm{P}<0.001, \mathrm{n}=16$.

The XRD spectra, not shown, allowed the Fe oxides goethite, hematite and maghemite to be identified. The $\mathrm{Hm} /(\mathrm{Hm}+\mathrm{Gt})$ ratio ranged from near zero in horizons Biv and $\mathrm{BCv} 2$ of profile $\mathrm{AC}$ 07 to 0.60 in horizon $\mathrm{Bt} 2$ of $\mathrm{AC} 10$ (Table 2). The prevalence of goethite over hematite in most of the samples was a result of the low Fe contents of the original materials (KÄMPF \& CURI, 2000). Sample color, which spanned a wide range of hues (2.5-10 YR), was positively correlated with the $\mathrm{Hm} /(\mathrm{Hm}+\mathrm{Gt})$ ratio: Hue $=10.736-[14.809 \cdot \mathrm{Hm} /$ $(\mathrm{Hm}+\mathrm{Gt})], \mathrm{R}=0.773, \mathrm{P}<0.001, \mathrm{n}=17)$. Most of the samples contained maghemite, the main pedogenic mineral with ferrimagnetic properties in the clay fraction.

As can be seen from Table 2, the estimated degree of $\mathrm{Al}^{3+}$ substitution in goethite differed widely among samples. The most frequent values fell in ranges suggesting (a) the formation of crystals in redoximorphic pedoenvironments or in soils from materials containing little $\mathrm{Al}^{3+}$ 
$\left(\mathrm{Al}^{3+}\right.$ substitution $\left.<15 \mathrm{~mol} \mathrm{~mol}^{-1}\right)$; and (b) the presence of moderately developed soils $\left(\mathrm{Al}^{3+}\right.$ substitution $=15-20 \mathrm{~mol} \mathrm{~mol}^{-1}$ ) (FITZPATRICK \& SCHWERTMANN, 1982). Only samples from profiles $\mathrm{AC} 02$ and $\mathrm{AC} 11$ exhibited $\mathrm{Al}^{3+}$ substitution values above $20 \mathrm{~mol} \mathrm{~mol}^{-1}$ and hence suggestive of highly weathered soils. The $\mathrm{Al}^{3+}$ substitution values for hematite, $0.05-0.08 \mathrm{~mol} \mathrm{~mol}^{-1}$, fell in the central range. The goethite-to-hematite $\mathrm{Al}^{3+}$ substitution ratio exceeded 0.5 in most samples, which suggests that the two minerals formed at different times under also different pedoenvironmental conditions (INDA JUNIOR \& KÄMPF, 2005).
Crystallinity was estimated from the mean coherence lengths $\left(\mathrm{MCL}_{\mathrm{hkl}}\right.$, Table 2). $\mathrm{MCL}_{110}$ and $\mathrm{MCL}_{111}$ for goethite ranged from 27 to $74 \mathrm{~nm}$ and 86 to $158 \mathrm{~nm}$, respectively. In those samples were both parameters could be determined, $\mathrm{MCL}_{111}$ exceeded $\mathrm{MCL}_{110}$, which is consistent with isodimensional development in the three crystallographic directions (SCHWERTMANN \& KÄMPF, 1985). The $\mathrm{MCL}_{104}$ and $\mathrm{MCL}_{110}$ values for hematite spanned the ranges 69-154 and $29-59 \mathrm{~nm}$, respectively. The fact that $\mathrm{MCL}_{104}$ values exceeded $\mathrm{MCL}_{110}$ values suggested that hematite crystals were longer than they were high and hence had the typical appearance of flat

Table 1 - Hue, total organic carbon (TOC), Fe contents in selectively extracted Fe oxides forms and their ratios, and index $K_{\mathrm{i}}$.

\begin{tabular}{|c|c|c|c|c|c|c|c|c|c|c|}
\hline \multirow{3}{*}{ Profile } & \multirow{3}{*}{ Soil } & \multirow{3}{*}{ Horizon } & \multirow{3}{*}{ Hue } & \multicolumn{6}{|c|}{ - } & \multirow{3}{*}{$K_{\mathrm{i}}$} \\
\hline & & & & TOC & Fes $\left(\mathrm{Fe}_{2} \mathrm{O}_{3}\right)$ & Fed & Feo & \multirow{2}{*}{ Fed/Fes } & \multirow{2}{*}{ Feo/Fed } & \\
\hline & & & & 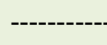 & $------g$ k & b & ------ & & & \\
\hline $\mathrm{AC} 01$ & EKo & Bhsx & $10 \mathrm{YR}$ & 11.8 & $6.3(9.0)$ & 0.6 & 0.5 & 0.10 & 0.83 & 1.68 \\
\hline $\mathrm{AC} 02$ & LAd & Bw2 & $10 \mathrm{YR}$ & 1.2 & $21.0(30.0)$ & 12.1 & 0.2 & 0.58 & 0.02 & 1.70 \\
\hline $\mathrm{AC} 04$ & PVal-1 & Bt1 & $2.5 \mathrm{YR}$ & 3.9 & $42.0(60.1)$ & 25.5 & 1.2 & 0.61 & 0.05 & 1.78 \\
\hline $\mathrm{AC} 04$ & PVal-1 & Bt2 & $2.5 \mathrm{YR}$ & 3.7 & $64.3(91.9)$ & 43.3 & 0.5 & 0.67 & 0.01 & 1.43 \\
\hline $\mathrm{AC} 04$ & PVal-1 & BCf1 & $2.5 \mathrm{YR}$ & 2.4 & $72.7(104.0)$ & 40.7 & 0.7 & 0.56 & 0.02 & 2.04 \\
\hline $\mathrm{AC} 05$ & PVal-2 & BA & $5 \mathrm{YR}$ & 4.4 & $33.6(48.1)$ & 14.3 & 1.6 & 0.43 & 0.11 & 3.42 \\
\hline $\mathrm{AC} 05$ & PVal-2 & Bt1 & $2.5 \mathrm{YR}$ & 3.6 & $42.7(61.1)$ & 20.0 & 1.0 & 0.47 & 0.05 & 3.16 \\
\hline $\mathrm{AC} 05$ & PVal-2 & $\mathrm{Bt} 2$ & $2.5 \mathrm{YR}$ & 2.9 & $54.5(77.9)$ & - & - & - & - & 3.37 \\
\hline $\mathrm{AC} 06$ & PVal-3 & BA & $2.5 \mathrm{YR}$ & 7.2 & $40.6(58.1)$ & - & - & - & - & 2.89 \\
\hline AC 06 & PVal-3 & Bt1 & $2.5 \mathrm{YR}$ & 5.9 & $47.6(68.1)$ & - & - & - & - & 2.71 \\
\hline $\mathrm{AC} 06$ & PVal-3 & $\mathrm{Bt} 3$ & $2.5 \mathrm{YR}$ & 3.3 & $73.4(105.0)$ & 32.9 & 0.9 & 0.45 & 0.03 & 3.25 \\
\hline AC 07 & VXo-1 & Biv & $10 \mathrm{YR}$ & 3.5 & $49.7(71.1)$ & 11.8 & 1.3 & 0.24 & 0.11 & - \\
\hline $\mathrm{AC} 07$ & VXo-1 & $\mathrm{BCv} 2$ & $10 \mathrm{YR}$ & 1.2 & $46.2(66.1)$ & - & - & - & - & - \\
\hline $\mathrm{AC} 08$ & $\mathrm{TCp}$ & Bt1 & $10 \mathrm{YR}$ & 4.3 & $43.4(62.1)$ & 16.8 & 1.5 & 0.39 & 0.09 & 3.30 \\
\hline $\mathrm{AC} 08$ & $\mathrm{TCp}$ & Bt2 & $10 \mathrm{YR}$ & 2.6 & $55.9(79.9)$ & 17.3 & 1.3 & 0.31 & 0.08 & 2.79 \\
\hline AC 09 & PVAal-1 & Bt1 & $5 \mathrm{YR}$ & 3.4 & $44.1(63.1)$ & 10.4 & 1.1 & 0.24 & 0.11 & 4.32 \\
\hline AC 09 & PVAal-1 & $\mathrm{Bt} 2$ & $5 \mathrm{YR}$ & 2.5 & $30.1(43.0)$ & 9.7 & 0.8 & 0.32 & 0.08 & 4.40 \\
\hline AC 10 & PVAal-2 & Bt1 & $5 \mathrm{YR}$ & 4.7 & $53.8(76.9)$ & 24.9 & 1.4 & 0.46 & 0.06 & 2.00 \\
\hline $\mathrm{AC} 10$ & PVAal-2 & $\mathrm{Bt} 2$ & $5 \mathrm{YR}$ & 3.2 & $56.6(80.9)$ & 20.9 & 1.2 & 0.37 & 0.06 & 2.27 \\
\hline AC 11 & VXo-2 & Biv1 & $10 \mathrm{YR}$ & 8.5 & $42.0(60.1)$ & 16.6 & 2.7 & 0.40 & 0.16 & 3.07 \\
\hline AC 11 & VXo-2 & Biv2 & 10YR & 5.8 & $58.7(83.9)$ & - & - & - & - & 3.48 \\
\hline
\end{tabular}

Fes: Fe extracted by $\mathrm{H}_{2} \mathrm{SO}_{4} ;\left(\mathrm{Fe}_{2} \mathrm{O}_{3}\right)$ Fe extracted by $\mathrm{H}_{2} \mathrm{SO}_{4}$ expressed as oxide form; Fed: Fe extracted by DCB-Na; Feo: Fe extracted by ammonium oxalate; $K_{\mathrm{i}}=\left(1,7 * \mathrm{SiO}_{2}\right) / \mathrm{Al}_{2} \mathrm{O}_{3}$ (ANJOS et al., 2013); EKo: Espodossolo Humilúvico Órtico; PVal: Argissolo Vermelho Alítico; VXo: Vertissolo Háplico Órtico; TCp: Luvissolo Cromico Pálico; PVAal: Argissolo Vermelho-Amarelo Alítico; VXo: Vertissolo Háplico Órtico (SANTOS et al., 2013). 
Table 2 - Hematite/(hematite + goethite) ratio, Fe by Al substitution and mean coherence lengths $\left(\mathrm{MCL}_{\mathrm{hkl}}\right)$ of hematite $(\mathrm{Hm})$ and goethite $(\mathrm{Gt})$ in the soil samples.

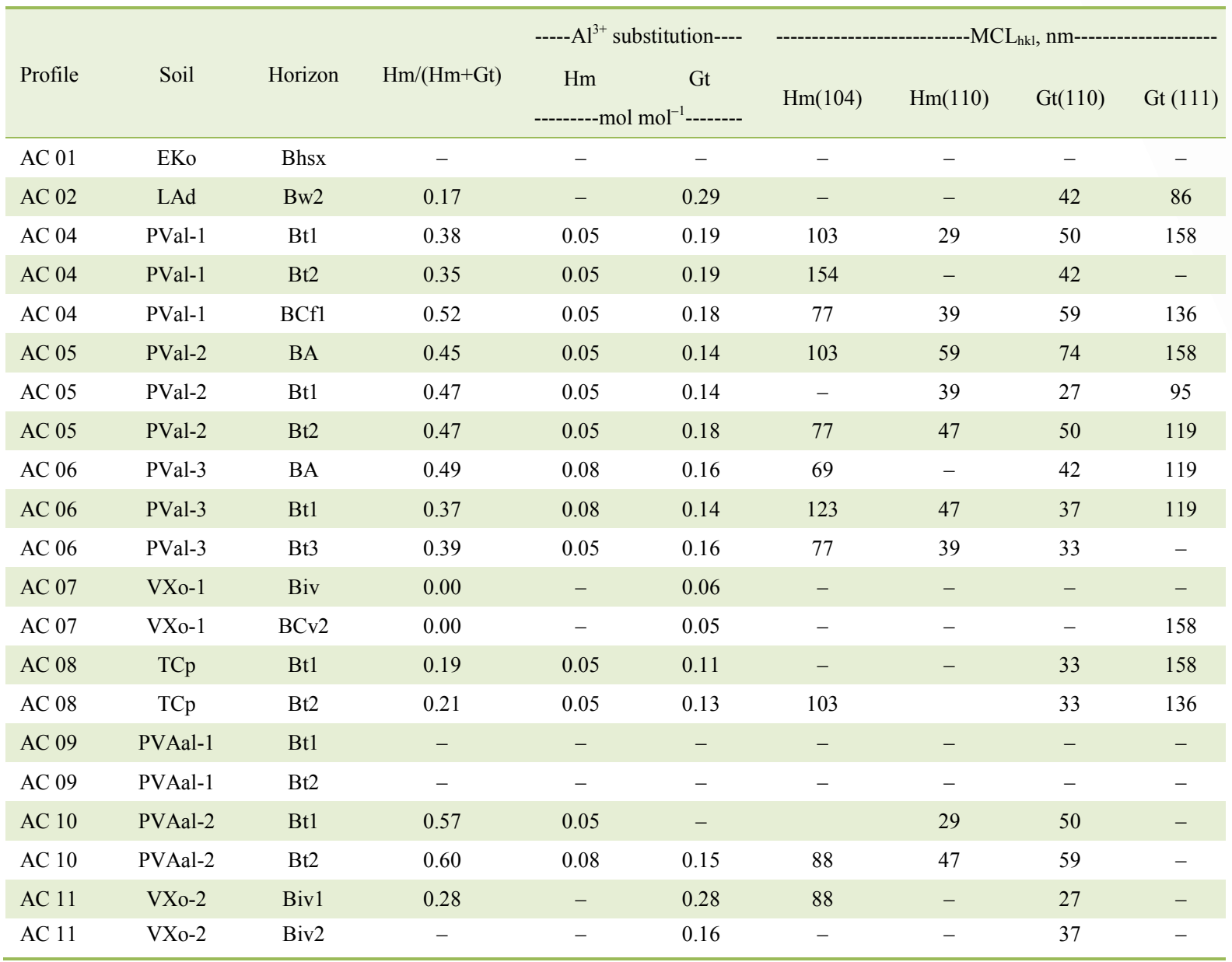

EKo: Espodossolo Humilúvico Órtico; PVal: Argissolo Vermelho Alítico; VXo: Vertissolo Háplico Órtico; TCp: Luvissolo Cromico Pálico; PVAal: Argissolo Vermelho-Amarelo Alítico; VXo: Vertissolo Háplico Órtico (SANTOS et al., 2013).

plaques in pedogenic hematite (SCHWERTMANN \& KÄMPF, 1985)

Overall, the studied soils, which developed from Cenozoic sedimentary rocks in the Solimões formation (Acre state, Brazil), have low contents in total $\mathrm{Fe}$ and $\mathrm{Fe}$ in pedogenic iron oxides. The substantial proportion of $\mathrm{Fe}$ in weathered minerals suggests that the soils are at an intermediate stage of weathering, where crystalline iron oxides prevail in the following sequence: goethite $>$ hematite $>$ maghemite. The conclusion that the soils are only moderately developed is supported by the increased frequency of goethite and hematite with medium degrees of $\mathrm{Al}^{3+}$ substitution. Finally, goethite is present mainly in isodimensional forms and hematite as flat plaques.

\section{DECLARATION OF CONFLICTING OF INTERESTS}

The authors have no conflict of interest to declare.

\section{REFERENCES}

ANJOS, L.H.C. et al. Guia de campo da IX Reunião Brasileira de Classificação e Correlação de Solos. Solos Sedimentares em Sistemas Amazônicos - Potencialidades e Demandas de Pesquisa. Brasília, DF: Embrapa, 2013. 204p. 
DONAGEMA, G.K. et al. Manual de métodos de análise de solos. 2 ed. Rio de Janeiro: EMBRAPA Solos, 2018. 573p.

FITZPATRICK, R.W.; SCHWERTMANN, U. Al-substituted goethite - an indicator of pedogenic and other weathering environments in South Africa. Geoderma, v.27, p.335-47, 1982.

INDA JUNIOR, A.V.; KAMPF, N. Variabilidade de goethita e hematita via dissolução redutiva em solos de região tropical e subtropical. Revista Brasileira da Ciência do Solo, v.29, p.851-866, 2005. Available from <http://www.scielo.br/scielo. php? script $=$ sci arttext\&pid $=$ S0100-06832005000600003\&ln $\mathrm{g}=\mathrm{en} \& \mathrm{nrm}=\mathrm{iso}>$. Accessed: Jul. 2018. Doi: 10.1590/S010006832005000600003 .

KÄMPF, N.; CURI, N. Óxidos de ferro: indicadores de ambientes pedogênicos. In: NOVAIS, R.F. et al. Tópicos em ciência do soloVolume 1. Viçosa: Sociedade Brasileira de Ciência do Solo, 2000. p.107-138.

KÄMPF, N.; SCHWERTMANN, U. The $5 \mathrm{M}-\mathrm{NaOH}$ concentration treatment for iron oxides in soils. Clays and Cay Minerals, v.30, p.401-408, 1982 .
McKEAGUE, J.A.; DAY, J.H. Dithionite and oxalate extractable Fe and $\mathrm{Al}$ as aids in differentiating various classes of soil. Canadian Journal of Soil Science, v.46, p.13-22, 1966.

MEHRA, O.P.; JACKSON, M.L. Iron oxide removal from soils and clays by a dithionite-citrate system buffered with sodium bicarbonate. Proceedings Clays \& Clay Mineral Conference, v.7, p.317-327, 1960 .

SANTOS, H.G. et al. Sistema brasileiro de classificação de solos. 3 ed. Rio de Janeiro: EMBRAPA Solos, 2013. 353p.

SCHULZE, D.G. The influence of aluminum on iron oxides: VIII. Unit-cell dimensions of Al-substituted goethites and estimation of Al from them. Clays Clay Miner., v.32, p.36-44, 1984.

SCHWERTMANN, U.; KÄMPF, N. Properties of goethite and hematite in kaolinitic soils of southern and central Brazil. Soil Science, v.139, p.344-350, 1985.

SCHWERTMANN, U. et al. The influence of aluminum on iron oxides. Part II. Preparation and properties of Al-substituted hematites. Clays Clay Miner., v.27, p.105-112, 1979. 